\title{
Online Learning Transition Based on Internet and E-Commerce Classroom Learning Management System (LMS)
}

\author{
Sudaryono $^{* 1}$, Alfiah Khoirunisa ${ }^{2}$, Abdullah Dwi Srenggini ${ }^{3}$ \\ ${ }^{1}$ Lecture Master of Information System Department, Universitas Raharja \\ ${ }^{2,3}$ Student Master of Information System Department, Universitas Raharja \\ E-mail: ${ }^{* 1}$ sudaryono@ raharja.info, ${ }^{2}$ alfiah@ raharja.info, ${ }^{3}$ abdullah.d@ raharja.info
}

\begin{abstract}
In the era of digital information, especially in the field of education, online learning methods are currently developing rapidly in the learning and teaching process. The aim of this project is to provide a uniform and consistent user interface in the new learning management system (LMS) for students and faculties and to promote super users who will assist the faculty in a smooth transition from. The curriculum template is provided in the LMS for online learning processes or called e-Learning and has various training opportunities with super users that are interactive so that online learning will be effective and quality. (57\%) report results from faculty feeling competent or very competent (36\%) in their ability to use. Canvas TM LMS after project implementation; There are several survey comments reflecting a positive response to the transition to Canvas ${ }^{\mathrm{TM}}$. This project produces quality, student-centered online learning. Where is in accordance with the standardized template framework
\end{abstract}

Keywords — Learning Management System, E-Commerce, Online Learning

\section{INTRODUCTION}

Introduction outlines the background of the problem being solved, the issues related to the problem being solved, the research reviews that have been done before by other researchers that are relevant to the research conducted. Information and communication technology (ICT) has been considered to be one of the pillars of contemporary society and part of everyday life for the general public. Included in the world of education, it is undeniable to be one of the fields that gets a touch in information and communication technology (ICT) ${ }^{[1]}$. At present, in various parts of the country as well as the types of educational institutions that have used ICT in the process of travel in a variety of ways and patterns based on different institutions. However, the use of a technology is considered a standard for most higher education institutions. For example, the lesson management system (LMS) and virtual learning environment ${ }^{[2]}$.

In this modern world, innovative industries are considered to be important places for learning in life. In modern teaching the individual approach is considered a supportive feature in technology based on Artificial Intelligence ${ }^{[3]}$. The formation of the path created by individual learning makes it possible to provide recommendations according to the level of knowledge, psychological picture and interests of students ${ }^{[4]}$. A study written by Ibatuliin and Anisimova has shown how the process of individual trajectories has an impact on the quality of achievement for academic students ${ }^{[5]}$. Other studies present a method used to classify questions on tests ${ }^{[6]}$. The researcher analyzes the information from the learning carried out by the previous journal writer, to the conclusion that introducing an individual learning path is considered to have a very important value. The process of creating a universal software package will certainly optimize and make the education process look more modern, can 
stimulate student interest and can also eliminate the possibility of assessment of existing values, which are positively assessed greatly affect the effectiveness of an educational process.

Acton (2005) suggests that training is one of the main employee-centered practices that is strongly associated with higher employee income and retention. In addition, training is very important for business because a large number of older workers reach retirement and college graduates have recently joined the workforce ${ }^{[7]}$.

Literature is considered to be very supportive of research in online education, although a student reports a preference for online learning, it is considered to be able to save time in the faculty. According to research conducted by Taft, Perkowski, and Martin in 2011, in the process of running online education is considered to be a heavier workload and intensity of effort given to a faculty compared to education in the classroom.

For students returning in rural areas who may have difficulty and flexibility to attend classes, transportation time, and costs, this is very useful in the presence of online learning methods ${ }^{[8]}$. New online learning methods are quickly emerging that move registered students from associate degrees to bachelor degrees.

The object of the research discussed in this paper has been carried out on a small campus that is in preparation to implement a learning management system (LMS) with a new style ${ }^{[9]}$. There are 3 (three) objectives that are explained in the form of points in this study: (a) to provide a transition facility without obstacles from an LMS platform to other LMS platforms in the information systems department; (b) to provide a standard media interface for users in a display as well as presentations from LMS for students; and (c) in order to create two super users in an Information Systems department who are judged to function as educators and sustainable resources for faculty ${ }^{[10]}$.

\section{RESEARCH METHODS}

For a faculty that had previously been in a clinical setting it could be a challenge in making the transition into the academic world, a challenge might arise when undergoing the transition process by approaching LMS online ${ }^{[11]}$. Motivating educators to develop innovative teaching and learning strategies as well as utilize all available resources and technology effectively ${ }^{[12]}$. Learning Management System is a tool that is considered to improve learning outcomes and can also promote success for students when inputting student orientation materials and available resources ${ }^{[13]}$.

A study conducted by Pena-Ayala (2014) states that modeling of student behavior is covered by more than $21 \%$ of research types or a literature on EDM and student modeling generally covers as much as $82 \%$ of existing research. What is being done in modeling in the current study is many types of behavior, such as guessing behavior, exploring the system, seeking help, misuse or underutilized assistance, and the desire to collaborate and etc ${ }^{[14]}$.

Students are given the opportunity to develop autonomy from the independent learning method. Gummesson \& Nordmark, 2012 revealed that online learning from both the perspective of students and faculty one of the biggest challenges was LMS. Members of the project being worked on can see the development carried out in the standardized user interface section for all faculties. The definition of hybrid online for this university is an individual program or academic program, teaching in a fully online format gives up to $70 \%$ but also learning through direct classes or practice covers around 30\%. A large number of faculties that may have minimal experience in education or developing an electronic or internet-based curriculum will be useful for taking hybrid courses. At the beginning of the new semester all practical or learning activities will be transferred to the LMS in accordance with administrative decisions and the faculty is expected to voluntarily participate in training sessions through online webinars (for example, the Faculties are fully responsible for the education they carry out alone). The author anticipates that the conversion into the new LMS will be very stressful especially for all faculties including additional lecturers, as well as the risk of disruption in the learning process for students who the authors estimate is very high 
because students are also expected to be able to independently utilize university resources in the process learn a new system.

\section{DESCRIPTION PROJECT}

In Indonesia, the new paradigm of the concept of learning in tertiary institutions seems to be regarded as aliens or aliens from outer space. The concept of teaching and learning still has meaning as an interaction between lecturers and students through a meeting that occurs in plain view in the classroom. Lecturers or instructors play a very dominant role in the lecture hall. In fact, effective learning should be very focused on the characteristics drawn from (the process of) learning. The intended learning, in fact, is an old paradigm that illustrates the dominance of lecturers in using various ways in giving lectures in tertiary institutions. In this context, show the difference between the old paradigm with the new paradigm related to the concept of higher education that is currently happening as seen in Table 1.

In Indonesia, it is not difficult to find references and research results that show the actual (method) of teaching in the classroom. Conversely, it is very difficult to find references and results of research on the concept of learning conducted in a virtual context or in virtual classrooms. Most of the reference books on the concept of learning in Indonesia talk about how to teach effectively in real classes, for example about how to interact with students, or how to motivate students to learn.

Table 1. Differences between the Old Paradigm and the New Paradigm of Higher Education

\begin{tabular}{|l|l|}
\hline \multicolumn{1}{|c|}{ Old Paradigm of Higher Education } & \multicolumn{1}{c|}{ New Paradigm of Higher Education } \\
\hline Subjects as given & $\begin{array}{l}\text { Choose courses as you wish } \\
\text { Registration and academic activities are open } \\
\text { throughout } \\
\text { Registration and academic activities are very } \\
\text { dependent on the academic calendar } \\
\text { The university is in a certain location } \\
\text { The length of study is limited by the } \\
\text { acquisition of a degree } \\
\text { Age ranges from 18-25 years } \\
\text { Depends on the institution's activities } \\
\text { The output / product is single } \\
\text { Students are treated as objects } \\
\text { Learning is done in the classroom } \\
\text { Multicultural in nature } \\
\text { The concept is a big unity } \\
\text { Single discipline } \\
\text { Focused on the institution } \\
\text { Government funded } \\
\text { Technology is an expensive investment }\end{array}$ \\
$\begin{array}{l}\text { Age from 18 years to infinity } \\
\text { Depends on market valuation }\end{array}$ \\
The information obtained can be reused \\
Students are considered as consumers \\
Learning can be done anywhere \\
Are global \\
The concept is small and disaggregated \\
Multi-disciplinary \\
Market focused \\
Funded through community funds \\
Technology as a distinguishing element \\
\hline
\end{tabular}


E-Learning, therefore, can be implemented at universities that only apply face-to-face learning systems, at universities that apply the concept of distance learning, and at universities that apply mixed models (see Figure 1). Implementation in distance learning colleges, basically, is aimed at improving the quality of teaching methods and mastery of lecture concepts and improving the teaching quality of a lecturer. However, nowadays, e-learning is also used by conventional tertiary lecturers as one of the face-to-face teaching methods to support learning that occurs in the classroom.

$\begin{array}{lll}\text { Face to face University } & \text { Dual models } & \text { Sistance education university } \\ \text { Single mode } & \text { (Combination) } \\ \begin{array}{l}\text { (Enchance the dominance } \\ \text { of teaching) }\end{array} & \begin{array}{l}\text { (Alternative teaching \& } \\ \text { learning transaction) }\end{array}\end{array}$

Figure 1. Implementation Of E-Learning In Higher Education

\section{IMPLEMENTATION PLAN}

In order to carry out this activity in order to run successfully towards improving the curriculum of a university, it is therefore necessary to request several submissions from the author. There are two interventions. First, to compile all online completion option programs, the way is to develop a template using the LMS provided by the campus. The goal is that the creation of an atmosphere of learning will run comfortably and easily in conducting online learning between lecturers and students. For students who are still confused in using LMS, this need can help in using LMS.

\section{FRAMEWORK}

We conceptualize training in "textbooks" which explain the use of web pages. On the main page on the web there are several types of choices, for example one to the Class page containing the "chapter" meeting. On each iDu page, lecturers and students can do individualization activities and make other activities, such as reading, and making portfolio profiles of students, discussions between students, doing assignments, or doing quizzes. This includes links to syllabi, policies for academics, support services for students.

Designing a supply chain usually involves determining the type of company (eg, toaster manufacturers, metal component makers) and the types of companies that can trade with each other, and then assigning students to examples of each type of company. The architecture also allows educators to evaluate student performance and to choose eCommerce elements (e.g., Email, EDI) and document types (e.g. warehouse invoices) that they will use in simulations [15].

In the online LMS learning process, a training schedule is created to complete a preparatory course for all, complete the learning schedule, to develop the mindset of students in online learning. There are several sessions in the training conducted. First, it is done during the odd semester. Second, individual training is conducted throughout the even semester until the LMS is launched.

To support the success of the project, collaboration of trainers and teaching staff is needed. Collaboration consists of scheduled meetings, structured deadlines for uploading documents, and individual courses for lecturers and students. In the first semester the spring semester will begin and scheduled emphasis on the course. 


\section{RESULTS AND DISCUSSION}

\section{A. Students}

During the project activities, the faculty is asked to receive input from the emails received, suggestions, and suggestions. At the completion of the project, all the faculties that teach in the survey determine effectiveness, and students are contacted by academic advisors to provide questions or rebuttal to the experience they have gained.

\section{B. Faculty}

All teaching staff and staff have the results of teaching assignments $(n=32)$ given the opportunity to practice LMS Canvas in group settings, through online webinars, or individually. For those who taught during the first 8 (eight) weeks of 2016 and those surveyed were conducted in the 6th (sixth) semester $(\mathrm{n}=34)$. Anonymously, there were 8 (eight) questionnaire items that had been distributed through Survey Monkey, and there were $58 \%$ of the survey results completed $(n=14)$. Table 2 to see the results.

Table 2. Faculty Surveys

\begin{tabular}{|c|c|c|}
\hline \multicolumn{3}{|l|}{ Faculty Surveys } \\
\hline Survey question & Results & Details \\
\hline What is your teaching position? & $\begin{array}{l}57 \% \\
29 \% \\
14 \%\end{array}$ & $\begin{array}{l}\text { Full time } \\
\text { Adjunct or part time } \\
\text { Academix advisor w/teaching responsbility }\end{array}$ \\
\hline $\begin{array}{l}\text { Before the spring semester of } 2016 \text {, had you } \\
\text { ever taught before using the CanvasTM LMC? }\end{array}$ & $\begin{array}{l}93 \% \\
7 \%\end{array}$ & $\begin{array}{l}\text { No } \\
\text { Yes }\end{array}$ \\
\hline How do you feel about the CanvasTM LMS? & $\begin{array}{l}50 \% \\
29 \% \\
21 \%\end{array}$ & $\begin{array}{l}\text { It is better then Oncourse TM }(n=7) \\
\text { I realyy like it, and I am glad that we changed ( } n=4) \text {. } \\
\text { No strong feelings. it is okay, but I can take it or leave it }(n=3) \text {. }\end{array}$ \\
\hline $\begin{array}{l}\text { How would you rate your feelings of competency } \\
\text { now in using CanvasTM in your classes? }\end{array}$ & $\begin{array}{l}57 \% \\
36 \% \\
7 \%\end{array}$ & $\begin{array}{l}\text { I am doing okay with it, but I have a lot more to learn }(n=8) \text {. } \\
\text { I am doing well, I think I understand most of the feature avaliable and use many of them }(n+5) \text {. } \\
\text { I am managing to get around in it, but I do not feel very competent overall }(n=7) \text {. }\end{array}$ \\
\hline $\begin{array}{l}\text { Please rank order the training you received } \\
\text { in CanvasTM with "l" as most helpful and }\end{array}$ & $\begin{array}{l}\text { 1. I did a } \\
\text { 2. I atten }\end{array}$ & $\begin{array}{l}\text { CanvasTM webinar }(n=3) \\
\text { led one more CanvasTM sessions at the faculty development .workshop }(n=7)\end{array}$ \\
\hline "8" as least helpful. & $\begin{array}{l}\text { 3. I just j } \\
\text { 4. I atten } \\
\text { 5. I watcl } \\
\text { 6. I comp } \\
\text { 7. I partic } \\
\text { 8. I read }\end{array}$ & $\begin{array}{l}\text { Imped right in and learned by trial and error }(n=11) \text {. } \\
\text { le a training session or workshop with the information technology support person }(n=10) \text {. } \\
\text { ed the PowerPoint lecture and presentation at the } 2015 \text { faculty educational meeting }(n=7) \\
\text { leted a self-directed checklist that guide me through developing my own CanvasTM pratice site }(n=8) \text {. } \\
\text { ipated in one-one-one CanvasTM training with a nursing faculty member }(n=7) \text {. } \\
\text { ne or more of the CanvasTM instructor guides }(n=7) \text {. }\end{array}$ \\
\hline $\begin{array}{l}\text { Please make any comments here abouts your } \\
\text { training, preperation, or utilization of CanvasTM } \\
\text { including any learning methods that were not listed here. }\end{array}$ & $\begin{array}{l}\text { - Would } 1 \\
\text { - Loving } \\
\text { modern f } \\
\text { - I apprec } \\
\text { - Having } \\
\text { - I like th } \\
\text { - Possibl } \\
\text { - I believ } \\
\text { - I believ } \\
\text { - Nursing }\end{array}$ & $\begin{array}{l}\text { ke continued educational sessions on how to unitilze functionality. } \\
\text { Canvas so far I hate getting out of my comfort zone to learn something new, but the multiple, more } \\
\text { catures are worth it. } \\
\text { iated the individual assistance/guidance in setting up my courses. } \\
\text { the course template setup was very helpful. } \\
\text { at the template for the courses are all the same--It makes it much easier for our students. } \\
\text { a students FAQ sheet to help them adjust. } \\
\text { I am doing well with Canvas and enjoy using it. } \\
\text { I am at the point where there are things about Canvas that I do not know. } \\
\text { faculty was a great asset to me in my transitiont to Canvas. }\end{array}$ \\
\hline
\end{tabular}

Half of the teaching staff, teaching full time, and half teaching one class online in the semester. A quarter of the faculty also teaches at least one traditional class besides online courses. And there is only one member who uses Canvas TM before the semester.

At first the faculties had questions about the type of training they had completed, after which they were asked to determine the order of their training priorities. That most faculties report "directly using the Canvas" survey results $(n=11)$. 
There are important points in the learning method, namely:

1. Participate in Canvas webinars.

2. Participate in one or more Canvas sessions on faculty development throughout the campus.

3. Doing continuous learning.

There was a response to how the teaching staff and other staff felt about them on Canvas ${ }^{\mathrm{TM}}$. Half of the survey results reported that it was better than the previous LMS, while the $29 \%$ survey results stated that they really liked it, and the $21 \%$ survey results stated that they could "take it or leave it". Here are the results of a survey that says $93 \%$ competent. (57\%) the faculties said they felt competent. (36\%) stated that they were very competent to use Canvas ${ }^{\mathrm{TM}}$ despite completing training. Finally, the survey results reflect a positive response to all faculties so that they can provide support and access to training resources.

\section{INDIVIDUAL APPROACH}

The most important goal in education is to reorient the training system to develop the learning function. Individual education trajectories are educational programs that can provide students to have a chosen subject including, development, and application of educational standards.

There are several external and internal factors that can affect students. First, internal factors are the characteristics of students' interests, emotional and physical conditions. Second, external factors include the influence of the environment on students.

The next challenge is that all faculties must adhere to the standardized templates. Apart from various training, faculty and staff are required to have a meeting to adopt the template used.

LMS helps students to get access to information and tools that can be used to create operational learning flows. Each student has unique knowledge based on their experience and abilities, so the choice of topics and students' courses also varies.

\section{SUGGESTED}

In the traditional view, the concept of learning in higher education is always illustrated through face-to-face meetings between lecturers and students that take place in the classroom. The new paradigm that emerges shows that learning no longer refers to face-to-face meetings even though the concept of social interaction in it is still maintained but is carried out through the internet. The presence of Internet technology, which makes it easy for people to interact without being bound by space and time, pushes the education sector into a new era utilizing elearning. Through e-Learning, the learning process can take place wherever and whenever desired. Higher education, therefore, must change the picture of society from an institution that is considered exclusive to a populist institution that serves the wider community.

The challenge that must be done is how to know the impact of students in accepting and implementing LMS online learning methods. Because some students may have prior Canvas exposure, it is quite difficult to be able to figure out how to evaluate them. Therefore, the decision made is to use the full online system as a comparison with hybrid online students because both programs implement LMS at the same time, but only hybrid students use standard templates. For hybrid students who are accustomed to having LMS programs that benefit from the start, due to faculty notice in the previous semester.

There are several dimensions regarding the application of e-learning including the organizational dimension, the infrastructure dimension, the dimension of funding sources, and the resource dimension. These four dimensions must be prepared in developing e-learning so that e-learning can truly facilitate the teaching and learning process. However, what needs to 
be noted is that the change in the concept of learning from conventional to e-learning must be linked to academic development strategies and to (change) the habits and beliefs of lecturers in implementing e-learning.

\section{REFERENCES}

[1] Aini, Q., Rahardja, U., Supriyati, R., \& Khoirunisa, A. (2019). Pengaruh Mailing Groups Sebagai Media Diskusi Dalam Motivasi Belajar Mahasiswa. JURNAL MEDIA INFORMATIKA BUDIDARMA, 3(1), 24-29.

[2] Moeins, A., Sudaryono, S., \& Khoirunisa, A. (2018). Utilization of Management of Writing Scientific in the Learning Process in Higher Education. Aptisi Transactions On Management, 2(1), 1-8.

[3] Rahardja, U. (2009, May). Artificial informatics. In 2009 4th IEEE Conference on Industrial Electronics and Applications (pp. 3064-3067). IEEE.

[4] Aini, Q., Rahardja, U., \& Khoirunisa, A. Blockchain Technology into Gamification on Education. IJCCS (Indonesian Journal of Computing and Cybernetics Systems), 14(2).

[5] Rahardja, U., Sudaryono, S., Santoso, N. P. L., Faturahman, A., \& Aini, Q. (2020). Covid-19: Digital Signature Impact on Higher Education Motivation Performance. International Journal of Artificial Intelligence Research, 4(1).

[6] Schnetter, V., Lacy, D., Mitchell, M., Bakrim, K., Allen, P. E., \& O'Neal, C. (2014). Course development for web-based nursing education programs. Nurse Education in Practice, 14(6), 635-640.

[7] Gummesson, C., \& Nordmark, E. (2012). Self-reflection in an online courseReflecting learning strategies? Advances in Physiotherapy, 14,87-93. http://dx.doi.org/10. 3109/14038196.2012.671848.

[8] Acton, T., Scott, M., \& Hill, S. (2005). E-education: Keys to success for organizations. 18' Bled eCommerce Conference, Bled. Slovenia June 6-8.

[9] Rahardja, U., Hariguna, T., \& Baihaqi, W. M. (2019, August). Opinion Mining on ECommerce Data Using Sentiment Analysis and K-Medoid Clustering. In 2019 Twelfth International Conference on Ubi-Media Computing (Ubi-Media) (pp. 168-170). IEEE.

[10] Stolze, M., \& Ströbel, M. (2003). Dealing with learning in ecommerce product navigation and decision support: the teaching salesman problem. In Proceedings of the Second Interdisciplinary World Congress on Mass Customization and Personalization.

[11] Wieting, J., Bansal, M., Gimpel, K., \& Livescu, K. (2015). Towards universal paraphrastic sentence embeddings. arXiv preprint arXiv:1511.08198.

[12] National League for Nursing (NLN) (2012). The scope of practice for academic educators. York, NY: National League for Nursing.

[13] Chipps,J., Kerr,J., Brysiewicz,P., \&Walters,F. (2015). Survey University students' perceptions of learning management systems in a low-resource setting using a technology acceptance model. Computers, Informatics, Nursing, 33(2), 71-77.

[14] Johnson, K. V. (2016). Improving adjunct nursing instructors' knowledge of student assessment in clinical courses. Nurse Educator, 41(2), 108-110.

[15] Peña-Ayala, A. (2014). Educational data mining: A survey and a data mining-based analysis of recent works. Expert systems with applications, 41(4), 1432-1462.

[16] Gašević, D., Dawson, S., Rogers, T., \& Gasevic, D. (2016). Learning analytics should not promote one size fits all: The effects of instructional conditions in predicting academic success. The Internet and Higher Education, 28, 68-84.

[17] McDonald, P. (2010). Transitioning from clinical practice to nursing faculty: Lessons learned. Journal ofNursing Education, 49(3), 126-131.

[18] Johnson, L., \& Smith, C. M. (2011). A hybrid course for the RN-to-baccalaureate curriculum. Nurse Educator, 36(4), 155-160.

[19] Wieting, J., Bansal, M., Gimpel, K., \& Livescu, K. (2015). Towards universal paraphrastic sentence embeddings. arXiv preprint arXiv:1511.08198. 
[20] Taft, S. H., Perkowski, T., \& Martin, L. S. (2011). A framework for evaluating class size in online education. The Quarterly Review ofDistance Education, 12(3), 181-197. 